University of Montana

ScholarWorks at University of Montana

$1-2006$

\title{
Habitat-Specific Impacts of Multiple Consumers on Plant Population Dynamics
}

John L. Maron

University of Montana - Missoula, john.maron@mso.umt.edu

Matthew J. Kauffman

Follow this and additional works at: https://scholarworks.umt.edu/biosci_pubs

Part of the Biology Commons

Let us know how access to this document benefits you.

\section{Recommended Citation}

Maron, John L. and Kauffman, Matthew J., "Habitat-Specific Impacts of Multiple Consumers on Plant Population Dynamics" (2006). Biological Sciences Faculty Publications. 240.

https://scholarworks.umt.edu/biosci_pubs/240

This Article is brought to you for free and open access by the Biological Sciences at ScholarWorks at University of Montana. It has been accepted for inclusion in Biological Sciences Faculty Publications by an authorized administrator of ScholarWorks at University of Montana. For more information, please contact

scholarworks@mso.umt.edu. 


\title{
HABITAT-SPECIFIC IMPACTS OF MULTIPLE CONSUMERS ON PLANT POPULATION DYNAMICS
}

\author{
John L. Maron ${ }^{1}$ And Matthew J. Kauffman \\ Division of Biological Sciences, University of Montana, Missoula, Montana 59812 USA
}

\begin{abstract}
Multiple consumers often attack seeds, seedlings, and adult plants, but their population-level consequences remain uncertain. We examined how insect and small mammal consumers influenced the demography and abundance of the perennial shrub, bush lupine (Lupinus arboreus). In grassland and dune habitats we established replicate experimental lupine populations in $81-\mathrm{m}^{2}$ plots that were either protected from, or exposed to, herbivorous voles and granivorous mice (via fencing) and/or root feeding insects (via insecticide treatment). Populations were initiated with transplanted seedlings in 1999 and 2000. We followed the demography of these cohorts, subsequent generations, and the seed bank for 5.5 years. Voles and insects killed many seedlings in dune (1999 only) and grassland (1999 and 2000) habitats. After 2000, insects and voles had minimal effects on seedling or adult survival. Seed predation by granivorous mice, however, greatly depressed seedling recruitment, resulting in lower adult lupine abundance in control plots vs. those protected from rodents. In grasslands, initial effects of voles and insects on seedling survival produced large differences among treatments in adult plant density and the cumulative number of seeds produced throughout the experiment. Differences among grassland populations in seed rain, however, had little influence on the magnitude of seedling recruitment into this habitat. Instead, recruitment out of a preexisting seed bank compensated for the lack of seed production in populations exposed to consumers. Shading by dense adults in plots protected from consumers limited seedling establishment within these populations. Although differences among populations in cumulative seed rain did not influence adult establishment, populations protected from consumers accumulated substantially larger seed banks than controls. These results illustrate how density dependence, habitat-specific seed dynamics, and particular demographic impacts of consumers interact to shape plant population responses to consumers.
\end{abstract}

Key words: bush lupine; granivory; insect herbivory; Lupinus arboreus; plant-consumer interactions; plant population dynamics; seed banks; voles.

\section{INTRODUCTION}

Despite decades of work, the role that consumers play in the population dynamics of perennial plants remains poorly resolved. We know that these consumers can inflict substantial damage to plants, thereby reducing their fitness. Reductions in fecundity caused by defoliation (Parker 1985, Bach 1994, Root 1996), predispersal seed predation (Waloff and Richards 1977, Hendrix 1984, Auld and Myerscough 1986, Louda 1989, Louda and Potvin 1995, Ehrlén 1997, Maron 1998, Maron et al. 2002), or postdispersal seed predation (Mittelbach and Gross 1984, Louda 1989, Crawley 1992, Hulme 1994, 1998, Edwards and Crawley 1999, Cummings and Alexander 2002) are especially common. Experimental work has also shown that herbivory can result in substantial seedling (Cates 1975, Dirzo and Harper 1982, Parker and Salzman 1985, Hulme 1994, Hanley et al. 1995, Goheen et al. 2004) or even adult plant mortality (Rausher and Feeny 1980,

Manuscript received 15 March 2005; revised 18 May 2005; accepted 24 May 2005; final version received 22 June 2005. Corresponding Editor: D. Pilson.

${ }^{1}$ E-mail: john.maron@mso.umt.edu
Bach 1994, Louda and Rodman 1996, Maron 2001, Rand 2002). Yet, while the negative influences of consumers on plant performance are well documented, how these effects translate across generations to influence plant population growth, distribution, or dynamics is unclear.

The best examples of population-level effects of consumers come from studies of fugitive plants with limited seed dormancy. For these species, plant recruitment is directly linked to seed production the previous year, and herbivore-imposed seed loss can reduce seedling recruitment and adult plant abundance (Louda 1982a, b, 1983, Louda and Potvin 1995, Fagan and Bishop 2000, Herrera et al. 2002). For many perennial plants, however, density dependence and seed dormancy can strongly buffer population-level effects of consumers. Density dependence can limit population-level consequences of herbivory if herbivore-imposed losses at one life stage are compensated for by reduced density-dependent mortality at a subsequent life stage. For example, seeds lost to predators can be compensated for by gains in the survival of seedlings that recruit at lower density than they would in the absence of pred- 
ators (Watkinson 1980, Cummings and Alexander 2002). Seed dormancy can buffer populations from negative consumer impacts if seeds accumulate in the seed bank, saturating safe sites for germination, and thus disconnecting seedling recruitment from seed input.

While the importance of density dependence and seed banks in mediating plant population responses to consumers are well appreciated in theory (Harper 1977), empirical estimations of the magnitude of compensatory density dependence and the life stages where this may be manifest are rare (but see Buckley et al. 2001, Goldberg et al. 2001). As well, our general understanding of how seed bank dynamics influence aboveground dynamics is limited (Kalisz and McPeek 1992, Cabin et al. 2000). As a result, how different functional groups of consumers influence spatiotemporal variability in seed demography, seedling recruitment, and plant population dynamics is not well understood (but see Horvitz and Schemske 1995).

Also uncertain is how often consumers influence habitat-specific patterns of population abundance or dynamics in plants. Consumer pressure can vary across environmental gradients (Holloway 1957, Louda 1982b, Lincoln and Mooney 1984, Galen 1990, Louda and Rodman 1996, DeWalt et al. 2004), and plant populations in adjacent habitats can sometimes exhibit markedly different dynamics (Louda and Rodman 1996). Yet, whether differences in plant abundance or dynamics between habitats results from habitat-specific patterns of consumer pressure is poorly resolved. Typically, habitat differences in plant abundance are ascribed to abiotic factors that vary between habitats rather than differences in herbivores.

Here we examine the extent to which various cryptic consumers that attack different plant life stages individually or interactively influence habitat-specific patterns of demography and population dynamics of an evergreen shrub, bush lupine (Lupinus arboreus). At our study sites, bush lupine population dynamics are strikingly different between grassland and dune habitats. In grasslands, high seedling recruitment in some years results in dense even-aged stands. These fastgrowing stands, however, frequently die off (Strong et al. 1995, Maron and Jefferies 1999), only to reestablish some years later from germination out of an abundant seed bank. In dunes, lupine populations are more stable (J. Maron, unpublished data), seedlings recruit at low density, and the adult population is sparse. To quantify how various consumers influence these habitat-specific patterns of bush lupine population growth and abundance we created experimental bush lupine populations in grasslands and dunes that were either protected from, or exposed to: (1) herbivorous voles (Microtus californicus) and granivorous mice (Peromyscus maniculatus and Rheithrodonomies megalotus), and/or (2) root-boring insects (ghost moths Hepialus californicus and cutworm larvae of the family Noctuidae). These different consumers attack specific plant life history stages. Voles kill seedlings, mice eat seeds, and rootboring insects (cutworms and ghost moths) kill seedlings and, in the case of ghost moths, kill adult plants (Davidson 1975, Maron and Simms 1997, Maron 1998). Thus, even though mice and voles were not manipulated separately we could easily infer and separate their individual effects. Our experiment quantified within-generation demographic effects of consumers on individuals that were used to found experimental populations, and across-generation effects on seed production, the survival of dispersed seeds, and the emergence and survival of second-generation plants that recruited into experimental populations. To our knowledge this is the first study to experimentally examine how multiple consumers influence the population abundance of a perennial plant with a seed bank.

\section{Methods}

\section{Lupine natural history}

Bush lupine (Lupinus arboreus) is a relatively short lived perennial shrub native to portions of the California coast. Plants set seed in their second summer in grasslands; in dunes plants grow more slowly and usually do not set seed until their third summer (M. Kauffman and J. Maron, unpublished manuscript). Lupine seeds are heavy and are dispersed near parent shrubs after explosive dehiscence from seed pods. Dispersed seeds are often consumed by mice (Maron and Simms 1997, 2001), but remain largely untouched by granivorous birds (E. Simms, unpublished data), and there are no seed harvesting ants at our site. Seeds begin to germinate with the onset of winter rains in November.

\section{Experimental setup}

In spring 1998 we established two experimental blocks at each of three grassland and dune sites on the University of California, Davis, Bodega Marine Reserve (Sonoma County, California, USA). Sites within habitats were separated by at least $500 \mathrm{~m}$ and blocks within sites were separated by at least $20 \mathrm{~m}$. Blocks consisted of four $9 \times 9 \mathrm{~m}$ plots separated by at least $5 \mathrm{~m}$ ( 24 plots per habitat, 48 plots total). Hereafter we refer to "plots" and experimental lupine "populations" interchangeably. Experimental plots in grasslands were initially free of existing lupine due to a large lupine die-off in summer 1997 (Maron et al. 2001). Lupines in the dunes did not die off, therefore we cleared the few existing lupines from dune plots in 1998 to ensure that experimental populations in both grasslands and dunes started with identical numbers of plants.

We randomly assigned plots within blocks to one of four factorial combinations of \pm rodent exclusion and \pm belowground insect herbivore exclusion. Rodent exclusion plots protected both seedlings from vole herbivory and seeds from granivorous mice; however, 
since mice and voles attack specific life stages of lupine we could separate their effects even within the same treatment. Insect exclusion plots protected plants from both ghost moths and cutworms. Unlike ghost moths, cutworms only occur in the dunes and only attack and kill lupine seedlings.

Rodent exclusion plots were surrounded by $90-\mathrm{cm}-$ tall fences made of PVC-coated welded wire $(0.635 \mathrm{~cm}$ mesh), dug $30 \mathrm{~cm}$ into the ground, and topped with $22.5 \mathrm{~cm}$ of aluminum flashing. Plots open to rodents were surrounded by an identical welded wire fence (but without PVC coating or flashing) with $5 \mathrm{~cm}$ diameter holes cut every $1.5 \mathrm{~m}$ along the bottom of the fence to allow entry by rodents. Voles that used gopher holes to colonize exclusion plots were eliminated by snap trapping (January-August 2000-2004). To control for possible differences in seed bank size among grassland plots, in summer 1998 we dug, sieved, and removed all lupine seeds (to a depth of $15 \mathrm{~cm}$ ) from five randomly placed and permanently marked $1-\mathrm{m}^{2}$ subplots within each experimental plot. We did not sieve subplots within dune plots because there is only a small and transient seed bank in dunes (Maron and Simms 1997; J. Maron and E. Simms, unpublished data).

To exclude belowground insect herbivores we sprayed the trunks of lupines and the soil immediately around them with $\sim 5-10 \mathrm{~mL}$ of the insecticide Dursban (12.5\% active ingredient diluted to $0.5 \mathrm{~mL}$ active ingredient/L water; Dow AgroSciences, Indianapolis, Indiana, USA) every 2-4 weeks, from February-May 2000-2003. These small quantities of Dursban, applied when early instar ghost moth larvae first colonize plants, kill all ghost moths inside lupine roots (Maron 1998, 2001; J. Maron, unpublished data). The active ingredient in Dursban (chlorpyrifos) has no toxic effects on bacterial or fungal populations (Revellin et al. 1992, Pozo et al. 1995). Because plants were sprayed during winter/spring when rainfall and fog drip is common, we did not treat control plants with water to control for the small amounts of water applied with the insecticide.

In January 1999 we transplanted and marked 49 lupine seedlings in an equally spaced $7 \times 7$ grid $(1.5 \mathrm{~m}$ from plot edge) across each plot. Due to high mortality of seedlings in this cohort, in 2000 we transplanted and marked an additional 20 seedlings in randomly selected open spaces in each plot. All transplanted seedlings were propagated in a greenhouse in December from local seeds. In 1999 and 2000, we removed any seedlings that recruited into plots so that we could start experimental populations at similar densities.

From January 1999 through April 2004, we censused these first two cohorts of plants every 2-4 weeks during the growing season (January-August). We conducted a final census of plants in early September 2004. Every summer from the time of first reproduction (2000) through 2003 we estimated seed production by counting all seed pods on every plant and harvesting 15 randomly chosen seed pods on each of 10 shrubs per plot to estimate the number of intact seeds per pod. Also during summer we estimated plant size by measuring canopy cover in two perpendicular directions and calculating circular canopy area from the average of these two diameter measurements.

Starting in January 2001 we marked and censused all seedlings that naturally recruited into experimental populations every 2-4 weeks. Henceforth we refer to these recruits as "second-generation seedlings" to differentiate these from the 1999 and 2000 cohorts that we experimentally planted. These second-generation seedlings could have been the progeny of individuals we transplanted into plots or they could have germinated from a preexisting seed bank. We followed the fate of all second-generation plants up until the end of the study in 2004.

From June to early July 2003, before plants set seed, we sampled the number of dormant seeds in the soil within each experimental population. These seeds could have originated from seed production during the course of the study (i.e., during summer 2000-2002) or from the existing seed bank. Within each plot, at four (grasslands) or five (dunes) locations chosen in a stratified random fashion we extracted a $30 \times 30 \times 15$ $\mathrm{cm}$ deep block of soil, sifted this through a $2-\mathrm{mm}$ mesh sieve, and recorded the number of lupine seeds remaining. To determine the number of dormant seeds that had accumulated in the seed bank solely from plants we had followed during the course of our study, we randomly selected and sieved seeds from one subplot (out of five available) from which we removed all lupine seeds at the beginning of the experiment. Viability of seeds sampled from the seed bank was tested via methods outlined in Appendix A.

\section{Analyses}

We used mixed-model ANOVAs (PROC MIXED module in SAS using Type III sum of squares; SAS Institute, Cary, North Carolina, USA) to examine the effect of insect and/or rodent exclusion on various vital rates. In these models, site $(n=3$ per habitat) and block nested within site ( $n=2$ per site) were random factors and rodent and insect exclusion (and their twoway interactions) were fixed factors. Response variables were seedling and adult survival (arcsine transformed), per capita seed production (calculated for all plants in a given cohort in each plot) and per population cumulative seed production (both $\log +1$ transformed), survival of second-generation seedlings (arcsine transformed), number of established second-generation lupines, the total number of plants (second-generation plants plus first-generation plants) at the end of the experiment, and seed bank size. Seed bank size was calculated as the mean number of seeds in the seed bank from the 4-5 samples we took from each population. For all analyses, except those involving seedling survival in 1999 and 2000, we analyzed data from 
grasslands and dunes separately because basic life history of plants (growth rates, fecundity, and seed dormancy) differs between habitats (M. Kauffman and J. Maron, unpublished manuscript). To analyze the impact of consumers on the survival of the first two cohorts of seedlings we used a nested mixed-model threeway ANOVA with block nested within site and site nested within habitat (block and site, random factors). Fixed factors in this model were habitat, rodent exclusion, insect exclusion, and their two- and three-way interactions. In all of the above analyses, we do not report statistical tests for block and site effects; however, they are accounted for in all ANOVA models.

Seedling survival in each cohort used to initiate experimental populations was calculated as the proportion of transplanted individuals that survived until midJanuary in the following year. Adult survival was calculated as the proportion of plants in each cohort that survived from mid-January (in either 2000 or 2001, the beginning of their second year of life) to September 2004, when the experiment was terminated. We separated survival estimates for seedlings and adults since consumers had different effects on seedlings vs. adult plants.

To test if recruitment was seed limited, we used linear regression of the cumulative per population seed production ( $\log +1$ transformed) on cumulative per population seedling recruitment for populations exposed to or protected from granivores. We performed this analysis on cumulative totals rather than regressing seedling recruitment in year $t+1$ on seed production in year $t$ because seedling recruitment can not only be from seeds produced in year $t$ but also from seeds produced in earlier years $(t-1, t-2$, etc. $)$ that have remained dormant in the soil. A linear relationship between seed production and seedling recruitment suggests that reductions in seed survival directly influence seedling recruitment.

To examine whether competition from adult shrubs reduced the survival of second-generation seedlings, for each habitat separately we regressed seedling survival (arcsine transformed) in year $t+1$ on total adult canopy cover per population in year $t$. Seedling survival was calculated as survival from emergence in winter of one year to January of the following year. Canopy cover per population was calculated as the sum of the canopy areas of each plant in that population.

\section{RESULTS}

\section{Dunes-survival and fecundity of plants used to found experimental populations}

In the first year of the experiment (1999) voles reduced bush lupine seedling survival in dunes by an average of $30 \%$ and cutworms reduced seedling survival by an average of $35 \%$ (Fig. 1A, Table 1). Seedlings attacked by voles were often cut in half, leaving a remaining bare stump that eventually (but not always) died. Cutworm herbivory could be easily diagnosed by a characteristic moon-shaped section that was removed from the very uppermost section of lupine root. We observed no ghost moths in dunes in 1999. In 2000, voles again reduced dune seedling survival, by an average of $26 \%$ (Fig. 1A, Table 1), but cutworms had no significant impacts on seedling survival (Table 1).

After their first year of establishment, the subsequent per capita seed production (Appendix B) and survival of adult plants in the 1999 and 2000 cohorts (survival from 1-4.5 $\mathrm{yr}$ for plants in the 1999 cohort and from $1-3.5 \mathrm{yr}$ for plants in the 2000 cohort) was not affected by vole or insect herbivory or their interaction (Appendix C). Because there was little compensatory mortality, the signature of high seedling mortality in dune plots exposed to consumers was still evident in adult populations several years later (Fig. 1B).

\section{Dunes-per population seed production and subsequent recruitment}

Although fewer plants in both cohorts established in dune plots exposed to vs. protected from rodents, there were no significant differences among populations in cumulative per population seed production (Fig. 2A). However, despite broadly comparable cumulative seed production among populations, those protected from granivorous mice experienced, on average, almost an order of magnitude more cumulative seedling recruitment $(718 \pm 157$ seedlings [mean \pm SE] $)$ than did populations exposed to granivores $\left(73 \pm 11.7 ; F_{1,18}=\right.$ 20.5, $P<0.0004$; Fig. 2B). For populations protected from granivores, there was a significant positive relationship between cumulative seed production across years and cumulative seedling recruitment over the life of the experiment (Fig. $3 \mathrm{~A} ; R^{2}=0.33, F_{1,10}=5.0, P$ $<0.05)$. In contrast, heavy seed predation in populations exposed to granivores eroded the relationship between cumulative seed input and cumulative seedling recruitment (Fig. $3 \mathrm{~A} ; R^{2}=0.17, F_{1,10}=2.0, P=0.18$ ). As a result, dune populations exposed to granivores had less seedling recruitment for the same level of seed input than did populations protected from granivores. Cumulative seedling recruitment was no different among populations protected from and exposed to insect herbivory (rodent $\times$ insect exclusion interaction: $\left.F_{1,18}=0.54, P=0.47\right)$.

\section{Dunes-survival of second-generation seedlings and population size at the end of experiment}

The survival of second-generation seedlings was not significantly affected by adult lupine cover (Appendix D) or by consumer treatment, except for voles in 2002, where seedling survival was actually higher in plots exposed to voles (Appendix E). (This was likely due to reduced shading from adult shrubs, as indicated by a marginally significant effect of adult cover [Appendix D].) Because compensatory density-dependence was of limited importance, greater recruitment into dune pop- 

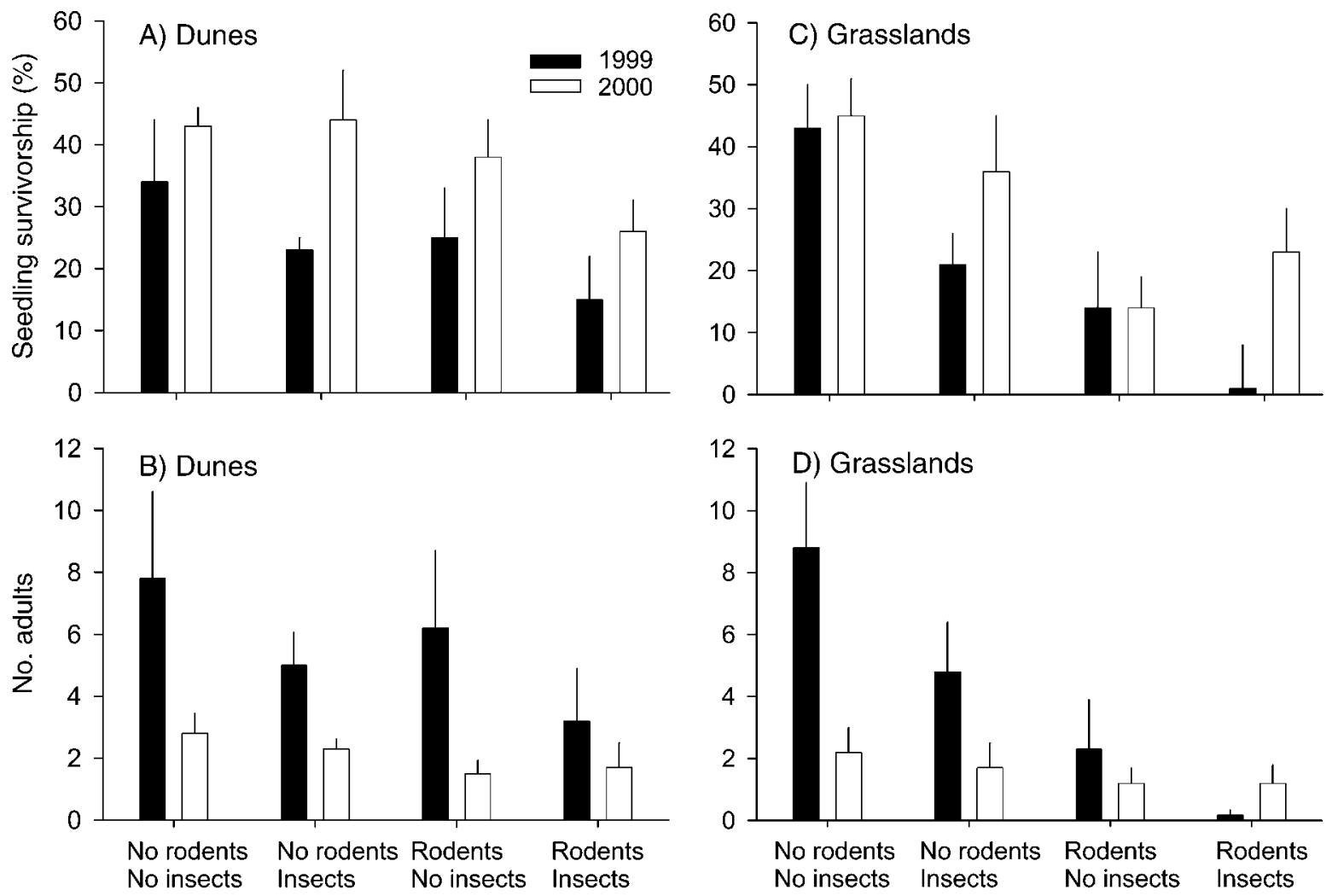

FIG. 1. Seedling survivorship and number of adults in experimental populations of bush lupine (Lupinus arboreus) protected from and/or exposed to rodents and belowground insect herbivores: seedling survivorship (means $+\mathrm{SE}$ ) in (A) dunes and (C) grasslands, January-December, in experimental cohorts planted in 1999 and 2000; number of adults (means $+\mathrm{SE}$ ) in (B) dunes and (D) grasslands, from 1999 and 2000 cohorts still alive in September 2004.

ulations protected from rodents translated to significantly greater establishment of second-generation adults in rodent-protected vs. rodent-exposed populations (Fig. 4A; $F_{1,15}=5.9, P<0.029$ ).

As well, populations protected from granivores had seed banks 3.3 times as large as those of populations exposed to rodents (Fig. 4B; $F_{1,15}=5.6, P<0.032$ ). On average, only $12 \pm 1.5 \%$ (mean $\pm \mathrm{SE}$ ) of seeds sampled from the seed bank germinated when scarified.

There was no effect of insect herbivores or an insect $X$ rodent interaction on the number of adult secondgeneration plants that established in dune populations

TABLE 1. Results from mixed-model ANOVAs testing for the effect of block nested within site nested within habitat; site nested within habitat; rodent exclusion; insect exclusion; and their interactions on the survival of seedlings planted in 1999 (first cohort) and 2000 (second cohort).

\begin{tabular}{|c|c|c|c|c|c|}
\hline \multirow[b]{2}{*}{ Source } & \multirow[b]{2}{*}{ df } & \multicolumn{2}{|c|}{ First cohort } & \multicolumn{2}{|c|}{ Second cohort } \\
\hline & & $\chi^{2}$ or $F \dagger$ & $P$ & $\chi^{2}$ or $F \dagger$ & $P$ \\
\hline \multicolumn{6}{|l|}{ Random effects } \\
\hline Block(site(habitat)) & 1 & 10.4 & 0.0006 & 1 & 0.15 \\
\hline Site(habitat) & 2 & 1.8 & 0.089 & 0 & 0.50 \\
\hline \multicolumn{6}{|l|}{ Fixed effects } \\
\hline Habitat & 1 & 0.44 & 0.57 & 2.95 & 0.09 \\
\hline Rodent exclusion & 1 & 21.6 & 0.0001 & 13.8 & 0.0007 \\
\hline Insect exclusion & 1 & 17.0 & 0.002 & 0.35 & 0.55 \\
\hline Rodent $\times$ insect & 1 & 0.87 & 0.36 & 0.04 & 0.85 \\
\hline Rodent $\times$ habitat & 1 & 4.99 & 0.03 & 1.25 & 0.27 \\
\hline Insect $\times$ habitat & 1 & 0.72 & 0.40 & 0.37 & 0.55 \\
\hline Rodent $\times$ insect $\times$ habitat & 1 & 0.42 & 0.52 & 2.8 & 0.11 \\
\hline Error & 33 & & & & \\
\hline
\end{tabular}

$\dagger \chi^{2}$ values are reported for random effects; $F$ values are reported for fixed effects. 

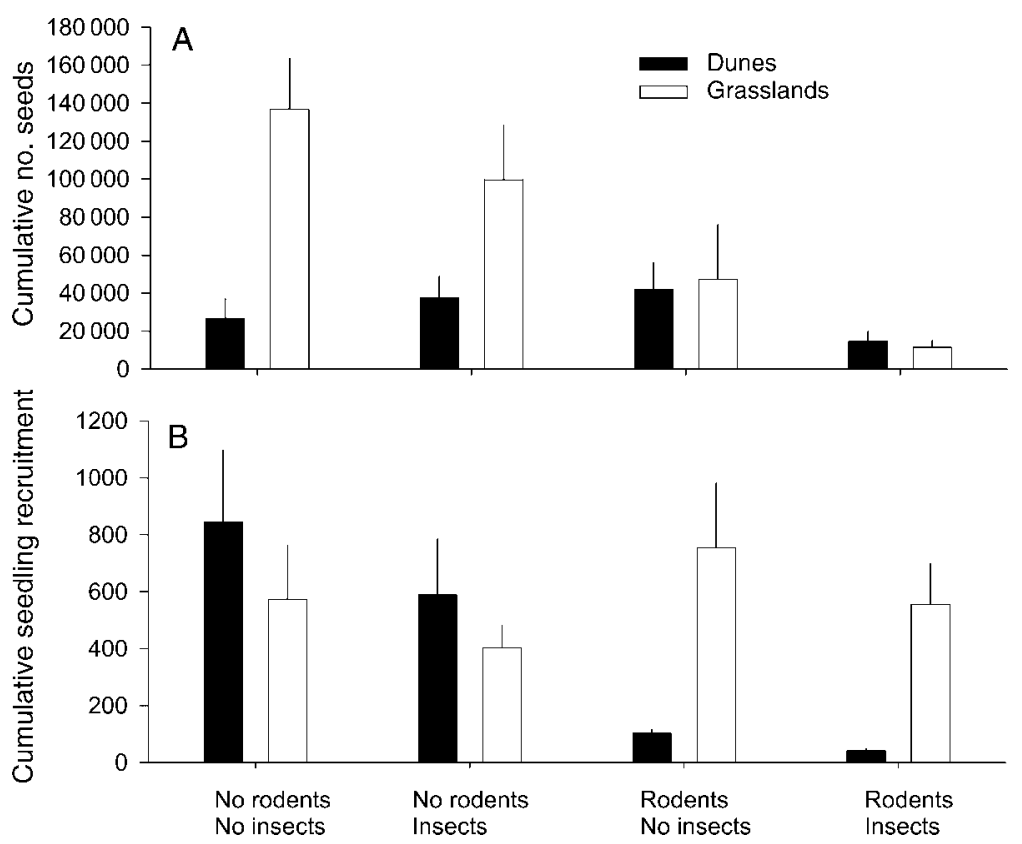

FIG. 2. Cumulative numbers of seeds and seedling recruitment in experimental populations of bush lupine protected and/ or exposed to rodents and belowground insect herbivores: (A) the cumulative number of seeds produced per population (mean + SE) from 2000 to 2003; (B) the cumulative seedling recruitment per population (mean + SE) from 2001 to 2004 . For effects of insects, voles, and their interaction, respectively, statistics for per-population seed production in dunes are $F=$ $0.01, P=0.9 ; F=0.69, P=0.42 ;$ and $F=3.2, P=0.09$. In grasslands the corresponding statistics are $F=0.42, P=$ $0.53 ; F=8.6, P<0.02$; and $F=2.1, P=0.17$. All df values are 1,15 .

$\left(F_{1,15}=2.8, P=0.10\right.$ and $F_{1,15}=1.07, P=0.32$ for the effect of insects and the insect $\times$ rodent interaction, respectively) or on seed bank size $\left(F_{1,15}=1.2, P=\right.$ 0.30 and $F_{1,15}=0.07, P=0.80$ for the effect of insects and the insect $\times$ rodent interaction, respectively). However, the total size of populations, which was the sum of all plants across all cohorts (i.e., first- plus secondgeneration plants), was significantly different across

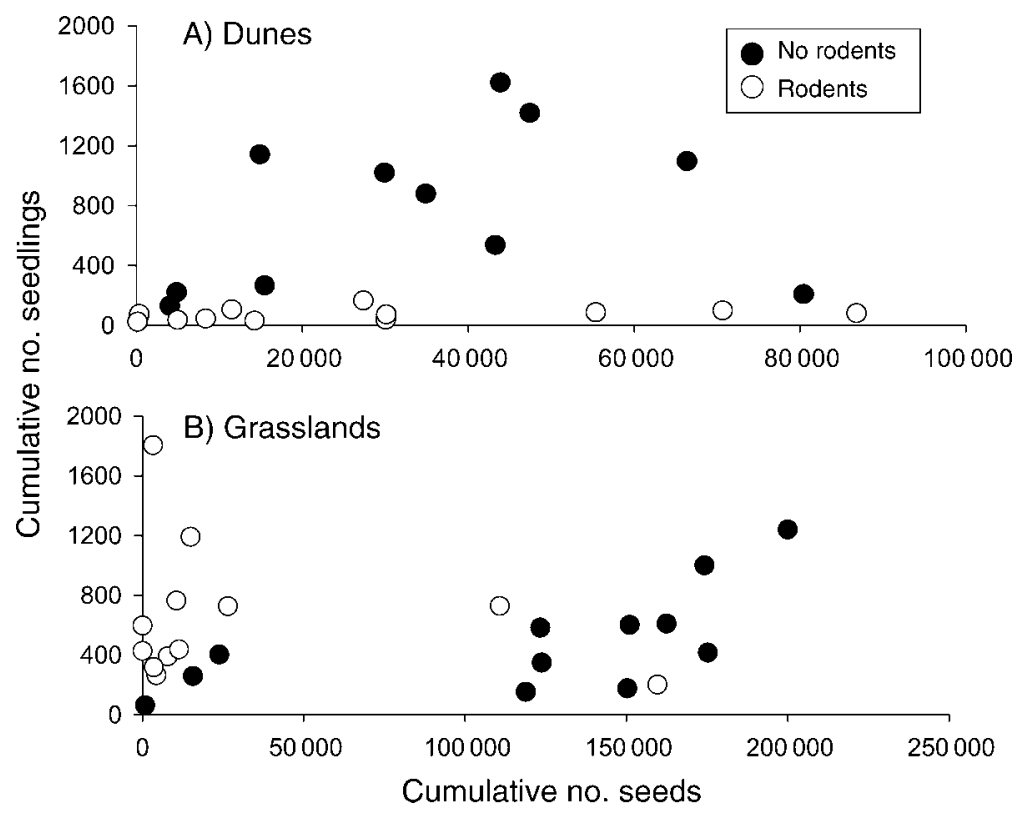

FIG. 3. The relationship between cumulative per-population seed production (2000-2003) and cumulative per-population seedling recruitment (2001-2004) in experimental populations of bush lupine open or closed to rodents in (A) dunes and (B) grasslands. In panel (A), one filled point close to the bottom of the $y$-axis is obscured by an open point. 

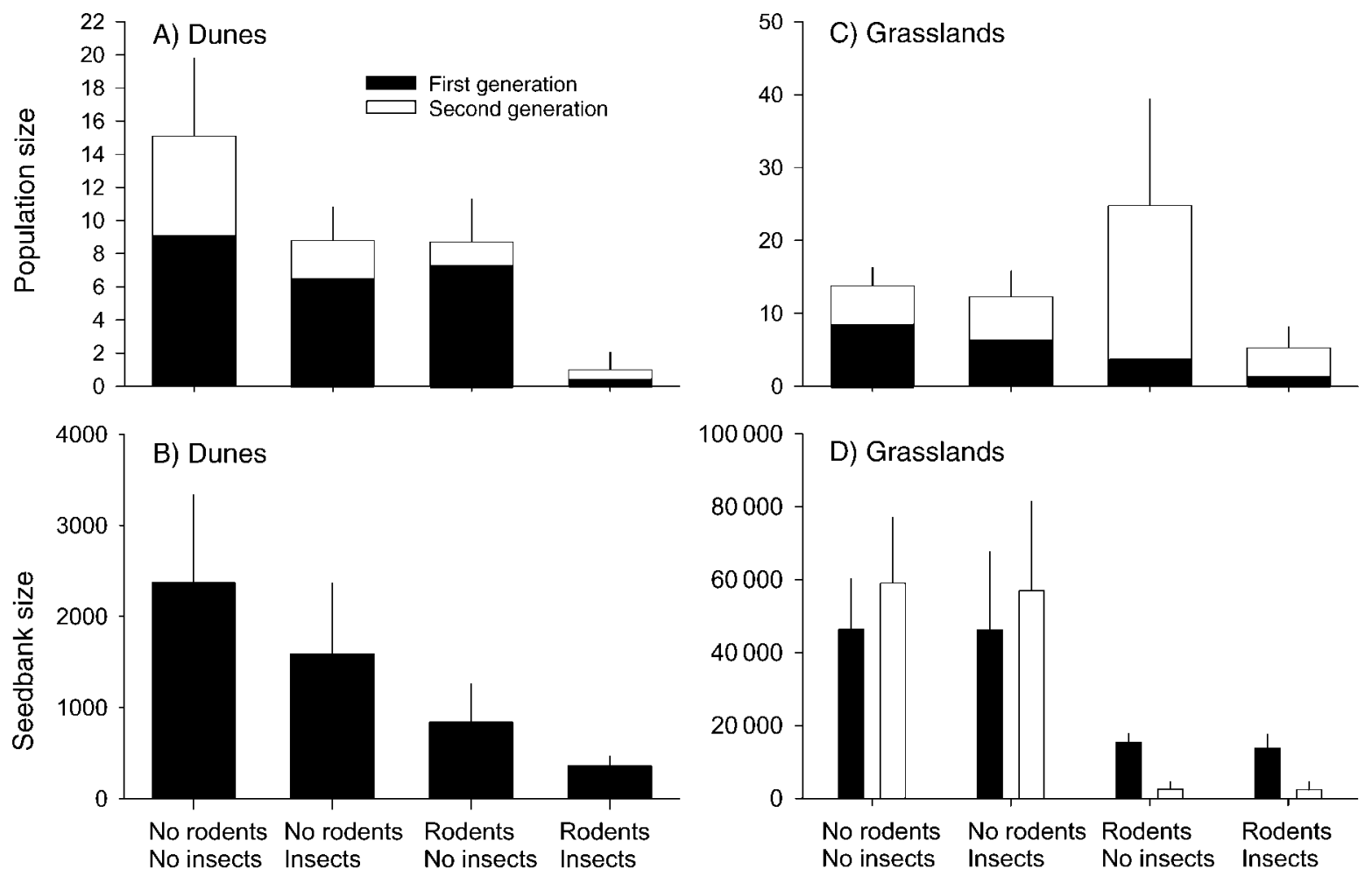

FIG. 4. Population sizes and seedbank sizes (means $+\mathrm{SE}$ ) in experimental populations of bush lupine protected from and/or exposed to rodents and belowground insect herbivores: total population size in (A) dunes and (C) grasslands (mean abundance of first- and second-generation plants at the end of the experiment [September 2004]); (B) dune and (D) grassland seed bank size in late spring 2003. In top panels, solid and open bars represent first- and second-generation plants, respectively. In panel (D), solid bars show total seed bank size; open bars show the size of the seed bank that accrued only during the course of the experiment.

treatments (rodent exclusion: $F_{1,15}=8.9, P<0.009$; insect exclusion: $F_{1,15}=8.4, P<0.011$; rodent $\times$ insect: $\left.F_{1,15}=0.36, P=0.56\right)$.

\section{Grasslands-survival and fecundity of plants used to found experimental populations}

In grasslands, voles had even greater effects on seedling survival than in dunes (as indicated by a significant habitat $\times$ rodent interaction; Table 1$)$. Vole herbivory depressed seedling survival by an average of $72 \%$ and 54\% in 1999 and 2000, respectively (Fig. 1C, Table 1). As well, ghost moths reduced seedling survival in 1999 by $61 \%$, but they had no effect on seedling survival in 2000 (Fig. 1C, Table 1). In 1999 there was no difference in average seedling survival between habitats, but in 2000 overall seedling survivorship was marginally higher in dunes than in grasslands (Table 1).

Per capita seed production (Appendix B) and survival (i.e., from their first year to the end of the experiment in September 2004) of plants from the 1999 and 2000 cohorts were unaffected by vole or insect herbivory (Appendix C). Similar to the dunes, initially high seedling mortality was still reflected in the size of adult grassland populations several years later (Fig. 1D).

\section{Grasslands-per population seed production and subsequent recruitment}

Cumulatively across years, grassland populations produced between 832 and $2 \times 10^{5}$ seeds (depending on site and treatment). In two plots there was no seed input because all plants in the 1999 or 2000 cohorts died before reproducing. Unlike in the dunes, cumulative per population seed production in grasslands differed significantly among consumer exclusion treatments (Fig. 2A). Due to their greater size, populations protected from rodents produced more seeds than populations exposed to rodents (Fig. 2A). Insect herbivores, however, did not significantly influence cumulative per population seed production (Fig. 2A).

Differences between grassland populations in $\mathrm{cu}$ mulative seed production did not significantly influence the magnitude of cumulative seedling recruitment (Fig. 2B). In sparse populations exposed to consumers, abundant recruitment out of a preexisting seed bank compensated for low in situ seed production. Populations that had minimal seed production had large numbers of seedlings recruiting into these populations (Fig. 3B). Furthermore, in striking contrast to the adjacent dunes, grassland plots protected from granivorous mice did 
not experience greater cumulative seedling recruitment compared to populations exposed to mice (Fig. 2B; $F_{1,15}$ $=1.9, P=0.19)$. Nor was there an effect of insect exclusion on cumulative recruitment $\left(F_{1,15}=1.62, P\right.$ $=0.22)$ or an insect $\times$ rodent exclusion interaction $\left(F_{1,15}=0.0, P=0.99\right)$. Recruitment out of the seed bank decoupled in situ seed production from recruitment, and as a result there was no significant relationship between cumulative seed production and cumulative seedling recruitment for populations either protected from (Fig. 3B; $R^{2}=0.28, F_{1,10}=3.8, P=0.08$ ) or exposed to granivores (Fig. $3 \mathrm{~B} ; R^{2}=0.004, F_{1,10}=$ $0.04, P=0.84)$

\section{Grasslands-survival of second-generation seedlings and population size at the end of experiment}

The survival of second-generation seedlings that recruited into grassland populations was inversely related to adult cover in 2001 and 2002 but not in 2003 or 2004 (Appendix D). From 2001 to 2003, there were no effects of voles or insects on the survival of secondgeneration recruits, except in 2002 where survival of seedlings was actually higher in plots exposed to vs. protected from voles (Appendix E). This result arose because seedlings that recruited into dense adult populations that were protected from rodents suffered higher density-dependent mortality (due to shading by adult lupines) than did seedlings that recruited into sparse adult populations that occurred in plots exposed to voles.

Because of compensatory recruitment out of the seed bank in plots open to consumers, and higher densitydependent mortality of seedlings in plots protected from consumers, there was no significant difference among treatments in either the number of second-generation plants that established within populations (Fig. $4 \mathrm{C}$; insect exclusion, $F_{1,15}=1.4, P=0.26$; rodent exclusion, $F_{1,15}=0.68, P=0.42$; and $F_{1,15}=1.8, P$ $=0.20$ for the insect $\times$ rodent interaction) or the total size of experimental populations (Fig. 4C; insect exclusion, $F_{1,15}=0.56, P=0.47$; rodent exclusion, $F_{1,15}$ $=2.18, P<0.16$; insect $\times$ rodent interaction, $F_{1,15}=$ $1.6, P=0.22$ ). Even a restricted comparison between the total population size between populations protected from all consumers and those exposed to all consumers revealed no significant difference between these groups (one-way ANOVA, $P=0.08$ ).

Although consumers did not influence the size of adult populations in grasslands, they did have large effects on seed bank density (Fig. 4D). Populations protected from rodents accumulated larger seed banks $($ seeds $=59100 \pm 17910[$ mean $\pm \mathrm{SE}])$ than did populations exposed to rodents $($ seeds $=2400 \pm 2061$; Fig. 4D; $\left.F_{1,15}=10.36, P<0.006\right)$. Insect exclusion had no effect on seed bank size $\left(F_{1,15}=0.0, P=0.98\right)$ nor was there a significant insect $\times$ rodent exclusion interaction on seed bank size $\left(F_{1,15}=0.03, P=0.87\right)$. An average of $30 \pm 2.2 \%$ of excavated dormant seeds germinated when scarified, over twice as many as those in the dunes $(12 \pm 1.5 \%)$.

\section{DISCUSSION}

Our experiment revealed that different consumers in different habitats have either chronic or episodic effects on bush lupine demography and that these divergent demographic effects have unique but strong impacts on lupine abundance. Here we summarize these consumer effects in the dune habitat, before outlining how they differ in grassland habitat. In dunes, high initial seedling mortality from herbivory led to smaller adult populations, yet these smaller populations exposed to consumers produced roughly similar numbers of seeds throughout the experiment compared to denser populations protected from herbivores (Fig. 3B). Despite similar seed production, seedling recruitment was almost an order of magnitude higher within populations protected from vs. exposed to rodent granivores, due to high levels of seed predation. Based on model fitting, we estimate that across years granivores consumed $\sim 94 \%$ of seeds dispersed into plots in dune habitat (M. Kauffman and J. Maron, unpublished manuscript). The positive correlation between cumulative seed input and cumulative seedling recruitment within populations protected from rodents clearly shows that lupine recruitment in dunes is seed, rather than microsite, limited. Since the survival of second-generation seedlings was broadly comparable across treatments, regardless of seedling and adult density, increased seedling recruitment into populations protected from granivores translated into gains in adult population size through time. These results for the dune habitat are novel in that many studies have documented high seed mortality due to rodent granivory (reviewed by Louda 1989, Crawley 1992, Hulme 1998) and even have shown how these reductions influence seedling recruitment (Edwards and Crawley 1989, Maron and Simms 2001, Herrera 2002). Yet, because subsequent density-dependent processes are often ignored, how these effects influence adult plant abundance is usually unknown (but see Brown and Heske 1990).

We found that protecting populations from granivores resulted in a second-generation plant population that was 15 times greater than the populations established in plots exposed to these consumers. Although voles and granivorous mice were not manipulated independently we could readily separate their impacts because they attacked unique life stages of plants. While voles and insects had strong episodic (but ultimately transient) effects on populations, granivorous mice had more forceful and lasting impacts. Densitydependent matrix models parameterized from our demographic data reveal that granivory reduces the longterm equilibrium population size of lupines in dunes by $90 \%$ (M. Kaufman and J. Maron, unpublished manuscript). 
The effects of consumers on lupine populations in grasslands were quite different than those in dunes, despite the fact that these habitats are in very close proximity. Initially, herbivore-imposed seedling mortality was even greater in grasslands than in dunes. Populations protected from high seedling mortality developed into dense adult stands, whereas populations exposed to consumers were generally sparse. A few populations that suffered especially intense seedling herbivory even went locally extinct. The resulting differences among treatments in adult population size were of sufficient magnitude to strongly influence cumulative per population seed production. Grassland populations protected from consumers produced over 11 times more seed throughout the experiment than did populations exposed to consumers. This led to large differences between treatments in seed bank size. These seed bank size differences between treatments were unlikely due to any synergistic effect of voles and granivorous mice; based on model-fitting techniques, we estimate that seed predation by mice in grasslands was minimal (M. Kauffman and J. Maron, unpublished manuscript).

Unlike in dunes, there was no relationship between cumulative seed production and cumulative seedling recruitment, even in plots protected from granivores. Thus, strong within-generation consumer effects did not immediately translate across generations to influence population abundance. Instead, recruitment out of a large preexisting seed bank compensated for differences in seed rain among populations. Grassland populations with few adults that received little seed input throughout the experiment still experienced substantial seedling recruitment due to the presence of a preexisting seed bank. Moreover, for some cohorts of seedlings, survival was higher in sparse adult populations with low canopy cover than it was in dense adult populations where seedlings were often shaded by existing lupines. These effects obscured any potential impact of granivores on seed survival in grasslands, and created conditions that essentially equilibrated seedling recruitment across populations. Ultimately, the considerable recruitment into grassland populations contributed minimally to the adult population because few seedlings survived due to shading by existing adults. These dynamics mirror what we have noted observationally over many years of work at our site. Seedlings often die when they recruit under the dense canopy of adult plants; significant new recruitment of lupines in grasslands only occurs in the absence of adults, most notably after die-off.

In the past, root herbivory by ghost moths has been responsible for killing dense cohorts of adult plants in grasslands (Strong et al. 1995, Maron 1998, 2001), facilitating future recruitment, and creating oscillatory dynamics (Strong et al. 1995, Maron and Jefferies 1999). We speculate that after the adult lupine population was killed by ghost moths in 1997 a lack of adult host plants caused the large ghost moth population to concentrate on lupine seedlings, with resultant high seedling mortality during the first year of our experiment (1999). Thereafter, we saw little evidence of ghost moth infestation of adult plants until summer 2002, when many adult plants not treated with insecticide were infested by ghost moths (J. Maron, unpublished data). (Only a tiny percentage of plants treated with insecticide had any evidence of ghost moth infestation, indicating that the insecticide treatment effectively reduced root-boring herbivory). Yet, even though lupines had high levels of infestation towards the end of the experiment, there were no significant effects of ghost moths on adult plant survival.

Why did we not detect strong effects of granivorous mice in grasslands as we did in dunes? Based on previous mark-recapture efforts it appears that the abundance of mice in these two habitats is broadly comparable (Maron and Simms 2001). However, in grasslands, dispersed lupine seeds may be more difficult for mice to find, due to a thick layer of senesced annual plants. In contrast, dispersed lupine seeds in dunes are often clearly visible in late summer and can commonly be found laying on the surface of open sand. As well, granivores may have more access to alternative food sources in grasslands than in dunes due to the greater diversity of grass and forb species in grasslands.

The fact that voles had effects on seedling survival in only three years out of six $(1999,2000$, and grasslands only in 2004) largely coincided with an apparent crash in the vole population. Voles in coastal California, as elsewhere, undergo large swings in population abundance (Batzli and Pitelka 1970). During the first two years of the experiment, voles were extremely abundant. However, based on annual spring surveys of the number of active vole runways, it appeared that vole populations were very low in the years 2001-2004 (J. Maron, unpublished data). Previous studies have shown that voles can influence grassland forb abundance and reduce tree intrusion into old fields (Ostfeld and Canham 1993, Ostfeld et al. 1997, Sirotnak and Huntley 2000, Manson et al. 2001, Howe et al. 2002), but ours is the first study to quantify how voles affect the dynamics of shrub populations.

While root-feeding insects and rodents had minimal effects on the final size of grassland shrub populations, voles had large effects on lupine seed bank size through their initial effects on seedling survival. Higher perpopulation seed production in dense experimental populations protected from consumers resulted over time in a dormant seed bank that was over three times larger than in consumer-free populations. Although the general importance of seed banks to plant population growth, age structure, persistence, and overall dynamics is well recognized (MacDonald and Watkinson 1981, Chesson 1983, Venable and Brown 1988, Kalisz and McPeek 1992), how consumers may modify these population processes through their impacts on the seed 
bank has remained a mystery. Using density-dependent matrix models we found that even occasional bouts of heavy vole herbivory and high seedling mortality can reduce long-term equilibrium grassland lupine abundance by $63 \%$ relative to populations protected from vole herbivory (M. Kauffman and J. Maron, unpublished manuscript).

Differences in population-level impacts of consumers between dunes and grasslands may be mediated by habitat-specific differences in seed bank dynamics. Lupine seeds from grasslands have greater inherent dormancy than do those from dunes (J. Maron, unpublished data; E. Simms, unpublished data). For example, in the current study, based on model fitting of field data from populations protected from rodents we estimate that a significantly lower percentage of lupine seeds produced by experimental plants germinated in grasslands $(0.2 \%)$ compared to dunes $(1.39 \%$; M. Kauffman and J. Maron, unpublished manuscript). As a result, $38 \%$ of the seeds produced by shrubs in consumerprotected grassland populations accumulated in the seed bank (an average of $59100 \pm 17910$ seeds [mean $\pm \mathrm{SE}]$ ) whereas only $29 \%$ of the seeds from dune populations protected from consumers accumulated in the seed bank (an average of $2370 \pm 966$ seeds). These differences between habitats in seedling emergence and seed dormancy fundamentally influence the relationship between seed input and seedling recruitment and therefore importantly mediate potential population-level impacts due to inherent, and consumer-induced, variation in seed rain.

Plant demography has provided much of the foundation for what we know about plant population dynamics (Harper 1977). Yet demographic work has remained largely descriptive, even as contemporary ecology has become increasingly experimental. This has limited our understanding of how various biotic interactions influence plant abundance (Ashman et al. 2004). Based on experimental demography we have shown that different consumers can have either episodic or chronic effects on plant performance, that these effects can vary strikingly across habitats, and that they can ultimately produce varied impacts on plant abundance.

\section{ACKNOWLEDGMENTS}

We thank D. Benner, J. Charles, J. Combs, M. Cooper, M. Greaves, D. Lowry, A. McCarthy, A. Mummert, C. Richey, E. Simms, C. Sweat, and S. Theodore for terrific field assistance. Early discussions with E. Simms helped motivate this work. P. Connors and R. Tinsman facilitated field work on the Bodega Marine Reserve and the Bodega Marine Laboratory graciously provided office space. This work was supported by NSF grant DEB-9726551 to JLM.

\section{Literature Cited}

Ashman, T.-L., T. M. Knight, J. A. Steets, P. Amarasekare, M. Burd, D. R. Campbell, M. R. Dudash, M. O. Johnston, S. J. Mazer, R. J. Mitchell, M. T. Morgan, and W. G. Wilson. 2004. Pollen limitation of plant reproduction: ecological and evolutionary causes and consequences. Ecology 85: $2408-2421$.

Auld, T. D., and P. J. Myerscough. 1986. Population dynamics of the shrub Acacia suaveolens (Sm.) Wild.: seed production and predispersal seed predation. Australian Journal of Ecology 11:219-234.

Bach, C. E. 1994. Effects of a specialist herbivore (Altica subplicata) on Salix cordata and sand dune succession. Ecological Monographs 64:423-445.

Batzli, G. O., and F. A. Pitelka. 1970. Influence of meadow mouse populations in California grassland. Ecology 51: 1027-1039.

Brown, J. H., and E. J. Heske. 1990. Control of a desertgrassland transition by a keystone rodent guild. Science 250:1705-1707.

Buckley, Y. M., H. L. Hinz, D. Matthies, and M. Rees. 2001. Interactions between density-dependent processes, population dynamics and control of an invasive plant species, Tripleurospermum perforatum (scentless chamomile). Ecology Letters 4:551-558.

Cabin, R. J., D. L. Marshall, and R. J. Mitchell. 2000. The demographic role of soil seed banks. II. Investigations of the fate of experimental seeds of the desert mustard Lesquerella fendleri. Journal of Ecology 88:293-302.

Cates, R. G. 1975. The interface between slugs and wild ginger: some evolutionary aspects. Ecology 56:391-400.

Chesson, P. L. 1983. Coexistence of competitors in a stochastic environment: the storage effect. Pages 188-198 in H. I. Freedman and C. Strobeck, editors. Population biology. Springer-Verlag, New York, New York, USA.

Crawley, M. J. 1992. Seed predators and plant population dynamics. Pages 157-192 in M. Fenner, editor. Seeds, the ecology of regeneration in plant communities. CAB International, Wallingford, UK.

Cummings, C. L., and H. M. Alexander. 2002. Population ecology of wild sunflower: effects of seed density and postdispersal vertebrate seed predators. Oecologia 130:274280.

Davidson, E. D. 1975. Demography of Lupinus arboreus at Bodega Head, California. Dissertation. University of California, Davis, California, USA.

DeWalt, S. J., J. S. Denslow, and K. Ickes. 2004. Naturalenemy release facilitates habitat expansion of the invasive tropical shrub Clidemia hirta. Ecology 85:471-483.

Dirzo, R., and J. L. Harper. 1982. Experimental studies on slug-plant interactions. II. The effect of grazing by slugs on high density monocultures of Capsella bursa-pastoris and Poa annua. Journal of Ecology 68:999-1011.

Edwards, G. R., and M. J. Crawley. 1999. Rodent seed predation and seedling recruitment in mesic grassland. Oecologia 118:288-296.

Ehrlén, J. 1997. Spatiotemporal variation in predispersal seed predation intensity. Oecologia 108:708-713.

Fagan, W. F., and J. G. Bishop. 2000. Trophic interactions during primary succession: herbivores slow a plant reinvasion at Mount St. Helens. American Naturalist 155:238251.

Galen, C. 1990. Limits to the distributions of alpine tundra plants: herbivores and the alpine skypilot, Polemonium viscosum. Oikos 59:355-358.

Goheen, J. R., F. Keesing, B. F. Allan, D. Ogada, and R. S. Ostfeld. 2004. Net effects of large mammals on Acacia seedling survival in an African savanna. Ecology 85:15551561.

Goldberg, D. E., R. Turkington, L. Olsvig-Whittaker, and A. R. Dyer. 2001. Density dependence in an annual plant community: variation among life history stages. Ecological Monographs 71:423-446.

Hanley, M. E., M. Fenner, and P. J. Edwards. 1995. An experimental field study of the effects of mollusc grazing on 
seedling recruitment and survival in grassland. Journal of Ecology 83:621-627.

Harper, J. L. 1977. The population biology of plants. Academic Press, New York, New York, USA.

Hendrix, S. D. 1984. Reactions of Heracleum lanatum to floral herbivory by Depressaria pastinacella. Ecology 65: 191-197.

Herrera, C. M., M. Medrano, P. J. Rey, M. Sanchez-Lafuente, M. B. Garcia, J. Guitian, and A. J. Manzaneda. 2002. Interaction of pollinators and herbivores on plant fitness suggests a pathway for correlated evolution of mutualism- and antagonism-related traits. Proceedings of the National Academy of Science 99:16823-16828.

Holloway, J. K. 1957. Weed control by insects. Scientific American 197:56-62.

Horvitz, C. C., and D. T. Schemske. 1995. Spatiotemporal variation in demographic transitions of a tropical understory herb: projection matrix analysis. Ecological Monographs 65:155-192.

Howe, H. F., J. S. Brown, and B. Zorn-Arnold. 2002. A rodent plague on prairie diversity. Ecology Letters 5:30-36.

Hulme, P. E. 1994. Rodent post-dispersal seed predation in grassland: magnitude and sources of variation. Journal of Ecology 82:645-652.

Hulme, P. E. 1998. Post-dispersal seed predation: consequences for plant demography and evolution. Perspectives in Plant Ecology, Evolution and Systematics 1:32-46.

Kalisz, S., and M. A. McPeek. 1992. Demography of an agestructured annual: resampled projection matrices, elasticity analyses, and seed bank effects. Ecology 73:1082-1093.

Lincoln, D. E., and H. A. Mooney. 1984. Herbivory on Diplacus aurantiacus shrubs in sun and shade. Oecologia 64: 73-176.

Louda, S. M. 1982a. Limitation of the recruitment of the shrub Haplopappus squarrosus (Asteraceae) by flower- and seed-feeding insects. Journal of Ecology 70:43-53.

Louda, S. M. 1982b. Distribution ecology: variation in plant recruitment over a gradient in relation to insect seed predation. Ecological Monographs 52:25-41.

Louda, S. M. 1983. Seed predation and seedling mortality in the recruitment of a shrub, Haplopappus venetus (Asteraceae), along a climatic gradient. Ecology 64:511-521.

Louda, S. M. 1989. Predation in the dynamics of seed regeneration. Pages 25-51 in M. A. Leck, V. T. Parker, and R. L. Simpson, editors. Ecology of soil seed banks. Academic Press, San Diego, California, USA.

Louda, S. M., and M. A. Potvin. 1995. Effect of inflorescence-feeding insects on the demography and lifetime fitness of a native plant. Ecology 76:229-245.

Louda, S. M., and J. E. Rodman. 1996. Insect herbivory as a major factor in the shade distribution of a native crucifer (Cardamine cordifolia A. Gray, bittercress). Journal of Ecology 84:229-237.

MacDonald, N., and A. R. Watkinson. 1981. Models of an annual plant with a seed bank. Journal of Theoretical Biology 93:643-653.

Manson, R. H., R. S. Ostfeld, and C. D. Canham. 2001. Longterm effects of rodent herbivores on tree invasion dynamics along forest-field edges. Ecology 82:3320-3329.

Maron, J. L. 1998. Individual and joint effects of below- and aboveground insect herbivory on perennial plant fitness. Ecology 79:1281-1293.

Maron, J. L. 2001. Intraspecific competition and subterranean insect herbivory: individual and interactive effects on bush lupine. Oikos 92:178-186.
Maron, J. L., J. K. Combs, and S. L. Louda. 2002. Convergent demographic effects of insect herbivory on related thistles in coastal vs. continental dunes. Ecology 83:3382-3392.

Maron, J. L., S. Harrison, and M. E. Greaves. 2001. Origin of an insect outbreak: escape in space or time from natural enemies? Oecologia 126:595-602.

Maron, J. L., and R. L. Jefferies. 1999. Bush lupine mortality, altered resource availability, and alternative vegetation states. Ecology 80:443-454.

Maron, J. L., and E. L. Simms. 1997. Effects of seed predation on seed bank size and seedling recruitment of bush lupine (Lupinus arboreus). Oecologia 111:76-83.

Maron, J. L., and E. L. Simms. 2001. Rodent limited establishment of bush lupine: field experiments on the cumulative effect of granivory. Journal of Ecology 89:578-588.

Mittelbach, G. G., and K. L. Gross. 1984. Experimental studies of seed predation in old-fields. Oecologia 65:7-13.

Ostfeld, R. S., and C. D. Canham. 1993. Effects of meadow vole population density on tree seedling survival in oldfields. Ecology 74:1792-1801.

Ostfeld, R. S., R. H. Manson, and C. D. Canham. 1997. Effects of rodents on survival of tree seeds and seedlings invading old fields. Ecology 78:1531-1542.

Parker, M. A. 1985. Size-dependent herbivore attack and the demography of an arid grassland shrub. Ecology 66:850860.

Parker, M. A., and A. G. Salzman. 1985. Herbivore exclosure and competitor removal: effects on juvenile survivorship and growth in the shrub Gutierrezia microcephala. Journal of Ecology 73:903-919.

Pozo, C., M. T. Martinez-Toledo, V. Salmeron, B. Rodelas, and J. Gonzalez-Lopez. 1995. Effect of chlorpyrifos on soil microbial activity. Environmental Toxicology and Chemistry 14:187-192.

Rand, T. A. 2002. Variation in insect herbivory across a salt marsh tidal gradient influences plant survival and distribution. Oecologia 132:549-558.

Rausher, M. D., and P. Feeny. 1980. Herbivory, plant density, and plant reproductive success: the effect of Battus philenor on Aristolochia reticulata. Ecology 61:905-917.

Revellin, C., B. de Canson, and G. Catroux. 1992. Effect of a mixture of chlorpyrifos and Lindane on the symbiosis of Bradyrhizobium japonicum and Soybean (Glycine max (L.) Merril). Pesticide Science 36:69-74.

Root, R. B. 1996. Herbivore pressure on goldenrods (Solidago altissima): its variation and cumulative effects. Ecology 77:1074-1087.

Sirotnak, J. M., and N. J. Huntly. 2000. Direct and indirect effects of herbivores on nitrogen dynamics: voles in riparian areas. Ecology 81:78-87.

Strong, D. R., J. L. Maron, P. G. Connors, A. Whipple, S. Harrison, and R. L. Jefferies. 1995. High mortality, fluctuation in numbers, and heavy subterranean insect herbivory in bush lupine, Lupinus arboreus. Oecologia 104:85-92.

Venable, D. L., and J. S. Brown. 1988. The selective interactions of dispersal, dormancy, and seed size as adaptations for reducing risk in variable environments. American Naturalist 131:360-384.

Waloff, B., and R. O. Richards. 1977. The effect of insect fauna on growth mortality and natality of broom, Sarothamnus scoparius. Journal of Applied Ecology 14:787-789.

Watkinson, A. R. 1980. Density dependence in single-species populations of plants. Journal of Theoretical Biology 83: 345-357.

\section{APPENDIX A}

Methods for testing seed viability (Ecological Archives E087-004-A1). 


\section{APPENDIX B}

Values for per capita seed production of first and second cohort plants in dunes and grasslands (Ecological Archives E087004-A2).

\section{APPENDIX C}

ANOVA results testing the effects of rodent and/or insect exclusion on adult survival of plants from the first (1999) and second (2000) cohort (Ecological Archives E087-004-A3).

\section{APPENDIX D}

Regression analyses testing the effects of adult cover on seedling survival (for 2001-2004 cohorts) in dunes and grasslands (Ecological Archives E087-004-A4).

\section{APPENDIX E}

ANOVA results testing the effects of rodent and/or insect exclusion on seedling survival (for 2001-2004 cohorts) (Ecological Archives E087-004-A5). 